\title{
Temporal relationship between the onset of oestrus, the preovulatory LH surge and ovulation in farmed fallow deer, Dama dama
}

\author{
G. W. Asher, M. W. Fisher*, J. F. Smith, H. N. Jabbour and C. J. Morrow \\ Ruakura Agricultural Centre, Ministry of Agriculture and Fisheries, Private Bag, Hamilton, New \\ Zealand; and ${ }^{*}$ Invermay Agricultural Centre, Ministry of Agriculture and Fisheries, Private Bag, \\ Mosgiel, New Zealand
}

\begin{abstract}
Summary. A study was conducted to determine the timing of ovulation relative to the onset of oestrus and the preovulatory LH surge in fallow deer. Mature fallow does were randomly allocated to two treatments $(\mathrm{N}=10$ per treatment) designed to synchronize oestrus on or about 17 May. Does assigned to Group 1 (prostaglandin-induced oestrus) each initially received single intravaginal CIDR [Controlled Internal Drug Release] devices for 13 days followed by an i.m. injection of $750 \mathrm{mg}$ cloprostenol on Day 12 (15 May) of the subsequent luteal cycle. Does assigned to Group 2 (progesterone-induced oestrus) each received CIDR devices for 13 days, with withdrawal occurring on 15 May. All does were run with crayon-harnessed bucks (10:1 ratio) from the start of synchronization (18:00 h 15 May). Ten does (5 per group) were blood sampled via indwelling jugular cannulae every $2 \mathrm{~h}$ for $72 \mathrm{~h}$ from cloprostenol injection or CIDR device withdrawal and the plasma was analysed for concentrations of progesterone and LH by radioimmunoassay. Does within each treatment were randomly allocated to an ovarian examination time of $12,16,20$ or $24 \mathrm{~h}$ after the onset of oestrus. Laparoscopy was repeated at $12-\mathrm{h}$ intervals until ovulation was recorded. The ovaries of does failing to exhibit oestrus were examined 72 and $86 \mathrm{~h}$ after cloprostenol injection or CIDR device withdrawal. A total of 17 does were observed to exhibit oestrus at a mean ( \pm s.e.m.) interval from treatment of $44.6 \pm 3.6 \mathrm{~h}$ for Group $1(\mathrm{~N}=9)$ and $34 \cdot 1 \pm 2 \cdot 5 \mathrm{~h}$ for Group $2(\mathrm{~N}=8)$. The incidence of ovulation from 34 laparoscopic examinations was $0 \%$ for intervals $<20 \mathrm{~h}, 50 \%$ at $24 \mathrm{~h}$ and $100 \%$ for intervals $>28 \mathrm{~h}$. There was no difference between animals in Groups 1 and 2. The onset of the preovulatory LH surge ( $n=8$ observations) occurred at the onset of oestrus, with maximum LH surge concentrations $(30 \mathrm{ng} / \mathrm{ml})$ occurring $6 \mathrm{~h}$ later. Of 3 does not exhibiting oestrus, 2 (Group 2) possessed active corpora lutea at CIDR device withdrawal and 1 (Group 1) possessed a large unruptured follicle 72 and $86 \mathrm{~h}$ after cloprostenol injection.

The data indicate that ovulation in fallow deer occurs $\sim 24 \mathrm{~h}$ after the onset of oestrus and $\sim 18 \mathrm{~h}$ after the peak of the preovulatory LH surge.
\end{abstract}

Keywords: fallow deer; reproduction; oestrus; ovulation; progesterone; LH

\section{Introduction}

Artificial insemination (AI) of farmed fallow deer (Dama dama) is an effective means of disseminating genes from bucks of high genetic merit more widely and more rapidly than through natural mating (Asher et al., 1988; Mulley et al., 1988). The success of AI is partly dependent on the time of semen deposition at a particular site relative to ovulation. Laparoscopic intrauterine AI (Maxwell, 1984) at a pre-determined interval from synchronized oestrus is the currently preferred method for 
fallow deer as it allows precise placement of small volumes of semen close to the site of fertilization (Asher et al., 1990). However, the appropriate timing of semen deposition relative to synchronization treatment, the onset of induced oestrus and ovulation have yet to be fully evaluated. Initial studies, in which does were laparoscopically inseminated $56-58 \mathrm{~h}$ after progesterone (CIDR-type S) withdrawal, achieved conception rates of $\sim 40 \%$ (Asher et al., 1988) whereas more recent studies have lengthened the interval to 65-70 h to achieve conception rates of between 60 and $70 \%$ (Asher et al., 1990). To improve AI effectiveness further we have determined the precise time of ovulation (follicular rupture) after prostaglandin (cloprostenol) or progesterone (CIDR device) synchronization treatment.

\section{Materials and Methods}

Animals and management. Twenty parous 8-year-old fallow does at the Ruakura Agricultural Centre $\left(37^{\circ} 46^{\prime} \mathrm{S}\right.$, $175^{\circ} 20^{\prime} \mathrm{E}$ ), with a mean $( \pm$ s.e.m.) liveweight of $44 \cdot 1 \pm 1.5 \mathrm{~kg}$, were drafted into a single mating group on $10 \mathrm{April}$ 1989. All had fawned in the previous December and their progeny were weaned in late March. The does were run continuously with a vasectomized buck from 14 April to 15 May. Thereafter, until 15 June they were run continuously with at least one fertile buck. The deer were contained in high-fenced paddocks within $200 \mathrm{~m}$ of an enclosed observation platform. They were grazed on ryegrass-clover pastures and offered supplements of meadow hay and whole-kernal maize.

Synchronization and detection of oestrus. The does were allocated to 2 treatment groups $(N=10$ does per group) balanced for liveweight. Group I does (prostaglandin-induced oestrus) had their initial oestrus synchronized on or about 3 May by use of an intravaginal progesterone-releasing device (CIDR-type S, 9\% progesterone; Agricultural Division, CHH Plastic Products Group Ltd, Hamilton, NZ). Single CIDR devices were inserted on 18 April and removed 13 days later on 1 May. At 18:00 h on 15 May each Group 1 doe was given an i.m. injection of $750 \mathrm{mg}$ cloprostenol ( $3 \mathrm{ml}$ Estrumate; Imperial Chemical Industries PLC, Cheshire, UK) to induce regression of the Day 12 corpus luteum, facilitating a subsequent return to oestrus (Asher \& Thompson, 1989). Group 2 does (progesteroneinduced oestrus) each received single intravaginal CIDR devices (CIDR-type G, 9\% progesterone) for a 13-day period from 3 May. CIDR devices were removed at 18:00 h on 15 May, i.e. the same time as cloprostenol was administered to Group 1 does.

The bucks were fitted with ram mating harnesses (Asher, 1985) throughout the period of association with does. Crayons were replaced at least every 2 or 3 days and daily observations were conducted from the observation platform to record crayon mating marks. Furthermore, observations for oestrus were performed at least every $2 \mathrm{~h}$ during the 72-h period following prostaglandin administration/CIDR device withdrawal (18:00 h on 15 May), either by telescope from the observation platform or by close inspection of each doe during blood sampling.

Blood sampling. The does were mustered into a covered handling shed, individually restrained in a cradle and blood sampled (jugular venepuncture into $10 \mathrm{ml}$ heparinized Vacutainers) three times weekly from 14 April to 20 June. Ten does selected for their quiet temperament, 5 each from Groups I and 2, were blood sampled every $2 \mathrm{~h}$ from 18:00 h on 15 May (prostaglandin administration/CIDR device withdrawal) to $18: 00 \mathrm{~h}$ on 18 May (72-h duration). Samples $(\sim 5 \mathrm{ml})$ were withdrawn from the right external jugular vein via indwelling catheters (Intracath 3122 ; Deseret Company, Sandy, UT, USA) inserted $34 \mathrm{~h}$ before the start of sampling. During the sampling period these does were kept in a separate mating group from the remaining does. Blood samples were centrifuged immediately after collection and the plasma stored at $-10^{\circ} \mathrm{C}$ pending assay.

Assessment of ovulation time. Does within each treatment group were allocated randomly to one of 4 time intervals $(12,16,20$ and $24 \mathrm{~h}$ after oestrus) for initial ovarian examination by laparoscopy. Ovarian examinations were repeated for 12 does at 12-h intervals until ovulation was recorded. This interval was shortened for 2 does to 4 and $8 \mathrm{~h}$ respectively after previous examination revealed ovulation to be imminent. Does that failed to exhibit oestrus $(\mathrm{N}=3)$ were examined by laparoscopy 72 and $86 \mathrm{~h}$ after prostaglandin administration/CIDR device withdrawal.

Laparoscopy was performed while the does were anaesthetized with an i.m. injection of $6.0 \mathrm{mg}$ ketamine hydrochloride (Ketaset: Bristol-Meyers Co., Syracuse, NY, USA) and 3.0 mg xylazine hydrochloride (Rompun; Bayer Leverkusen, West Germany) per $\mathrm{kg}$ liveweight. External puncture wounds were treated with topical antibiotic powder (Aureomycin; Cynamid N.Z. Ltd, Auckland, NZ) following laparoscopy and $10 \mathrm{ml}$ of a long-acting antibiotic (Propen LA; Glaxo N.Z. Ltd, Auckland, NZ) were administered by i.m. injection. Anaesthesia was reversed with an i.v. injection of $0.5 \mathrm{mg}$ yohimbine hydrochloride (Recervyl; Aspiring Animals Services, Wanaka, NZ) per kg liveweight.

The occurrence and siting of regressed corpora lutea (corpora albicantia), large follicles and ovulation points were recorded during ovarian examination. Ovulation was deemed to have occurred when a follicle had ruptured, as evidenced by focal haemorrhagic tissue on the surface of the ovary.

Hormone assays. Plasma progesterone concentrations were measured in duplicate by direct radioimmunoassay. The rabbit antiserum against progesterone-11-BSA conjugate was used at final dilution of 1:200 $000 .{ }^{125}$ I-labelled 
progesterone (Amersham International PLC; Amersham, UK) was used as the tracer. The only significant crossreaction of a wide range of steroids tested in the assay was cholesterol $(1.5 \%)$. Serial dilutions of pooled plasma samples with high concentrations of immunoreactive progesterone gave inhibition curves parallel to those generated for progesterone in buffer. All samples from an individual doe were included within a single assay. Samples with low, medium and high concentrations of progesterone were included as control samples at frequent intervals in each assay. The inter-assay coefficients of variation were $15.8 \%$ for the low control (mean concentration $=2.13 \mathrm{ng} / \mathrm{ml}$ ), $14.5 \%$ for the medium control $(7.18 \mathrm{ng} / \mathrm{ml})$ and $9.3 \%$ for the high control $(16.4 \mathrm{ng} / \mathrm{ml}$ samples respectively). The intra-assay coefficients of variation were $12 \cdot 6,3 \cdot 8$ and $7 \cdot 4 \%$ for the 3 control samples respectively. Sensitivity, defined as the first point on the standard curve that was significantly different from zero, was $0 \cdot 10 \mathrm{ng} / \mathrm{ml}$.

Plasma LH concentrations were determined in duplicate using a heterologous radioimmunoassay procedure described for sheep plasma by Scaramuzzi et al. (1970) and validated for fallow deer plasma (Asher et al., 1986). The inter-assay coefficient of variation, calculated from determinations of deer control samples (mean concentration $=$ $8.74 \mathrm{ng} / \mathrm{ml})$ in each assay $(n=3)$ was $9.6 \%$. The intra-assay coefficient of variation for multiple determinations of the same control sample was $9.0 \%$. All samples from an individual doe were included within a single assay. The least amount distinguishable from zero was $0 \cdot 30 \mathrm{NIH}-\mathrm{LH}-\mathrm{S} 11 \mathrm{ng} / \mathrm{ml}$.

\section{Results}

\section{Plasma progesterone profiles}

Mean plasma progesterone profiles of the 10 does in Group 1 (prostaglandin-induced oestrus) and 8 does in Group 2 (progesterone-induced oestrus), all of which exhibited induced oestrus, are presented in Fig. 1. The first elevation in plasma progesterone concentrations represents primarily exogenous progesterone derived from the intravaginal CIDR devices. Does in Group 1 exhibited normal luteal development following CIDR device withdrawal but this was terminated by cloprostenol injection 13 days after oestrus. Following prostaglandin-induced oestrus on or about 17 May, 8 does in the group exhibited an apparently normal luteal cycle, while the 2 remaining does conceived and maintained luteal function (Fig. 1a). Similarly, of the 8 does in Group 2, 5 exhibited normal luteal cycles and 3 conceived following progesterone-induced oestrus on or about 17 May (Fig. 1b). Two does in Group 2 were excluded from the profiles in Fig. 1 as they failed to synchronize, probably because of the presence of active corpora lutea at CIDR device withdrawal.

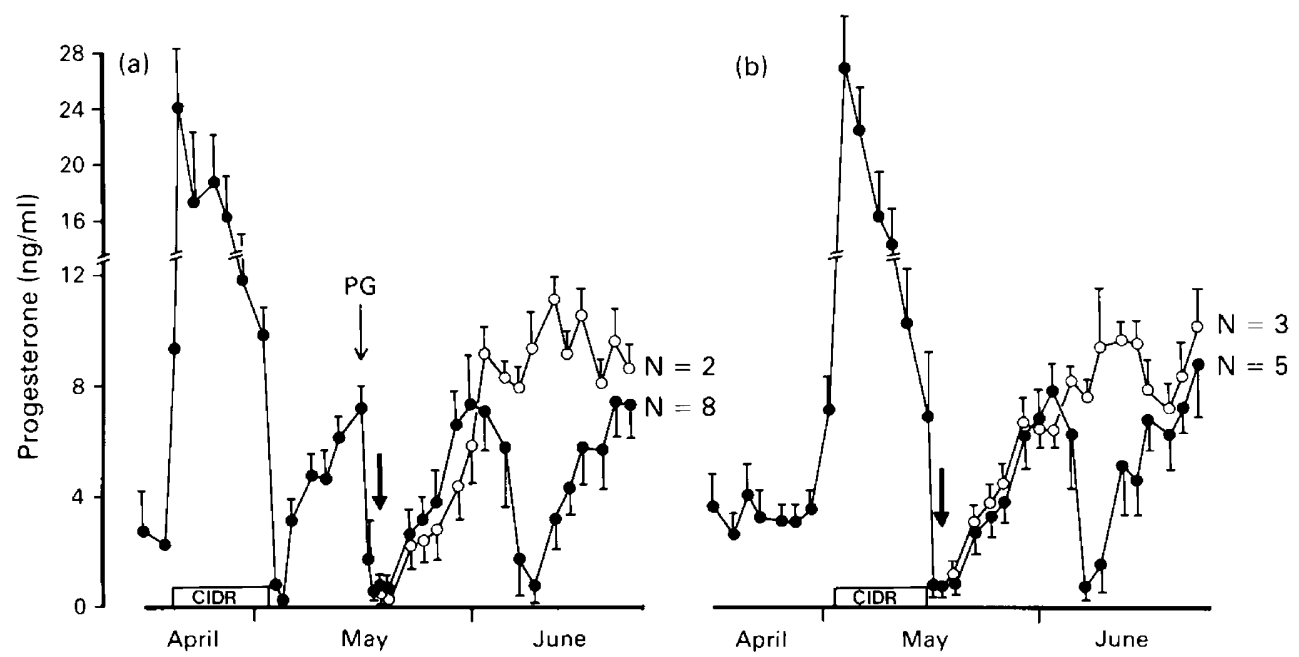

Fig. 1. Profiles of mean ( \pm s.e.m.) plasma progesterone concentrations of fallow does during and after different treatment regimens designed to synchronize oestrus on 17 May. (a) Group 1 does $(\mathrm{N}=10)$; initial 13-day CIDR device treatment followed by an i.m. injection of prostaglandin analogue on Day 12 of the subsequent cycle; (b) Group 2 does $(\mathrm{N}=8)$; 13-day CIDR device treatment alone. Arrows indicate the mean times of oestrus and open circles after 17 May indicate mean values for does that conceived to the synchronized oestrus. 


\section{Timing of ovulation relative to the onset of oestrus}

There were 17 does detected in oestrus at a mean ( \pm s.e.m.) post-treatment interval of $44.6 \pm 3.6 \mathrm{~h}$ (Group 1; $\mathrm{N}=9)$ and $34.1 \pm 2.5 \mathrm{~h}($ Group $2 ; \mathrm{N}=8)(P>0 \cdot 1$; Student's $t$ test). From 34 laparoscopic examinations of post-oestrous does from both groups, the incidence of ovulation was $0 \%$ for intervals $<20 \mathrm{~h}, 50 \%$ at $24 \mathrm{~h}$ and $100 \%$ for intervals $>28 \mathrm{~h}$ for both groups (Table 1 ). Of 3 does failing to exhibit oestrus, 2 (Group 2) possessed large, active mid-cycle corpora lutea $72 \mathrm{~h}$ after CIDR device withdrawal and one (Group 1) possessed a large unruptured follicle 72 and $86 \mathrm{~h}$ after cloprostenol injection. One Group 1 doe exhibited a double ovulation, with follicular rupture occurring in both ovaries between 20 and $32 \mathrm{~h}$ after oestrus.

Table 1. Incidence of ovulation recorded from laparoscopic ovarian examinations at various intervals from the onset of oestrus

\begin{tabular}{|c|c|c|c|c|c|c|}
\hline \multirow[b]{2}{*}{$\begin{array}{l}\text { Hours from } \\
\text { the onset } \\
\text { of oestrus }\end{array}$} & \multicolumn{2}{|c|}{ Group 1 does $(N=9)$} & \multicolumn{2}{|c|}{ Group 2 does $(\mathrm{N}=8)$} & \multicolumn{2}{|c|}{ Total $(N=17)$} \\
\hline & $\begin{array}{c}\text { No. of } \\
\text { laparoscopic } \\
\text { observations }\end{array}$ & $\begin{array}{l}\text { Ovulation } \\
\text { incidence }\end{array}$ & $\begin{array}{c}\text { No. of } \\
\text { laparoscopic } \\
\text { observations }\end{array}$ & $\begin{array}{l}\text { Ovulation } \\
\text { incidence }\end{array}$ & $\begin{array}{l}\text { Total no. of } \\
\text { laparoscopic } \\
\text { observations }\end{array}$ & $\begin{array}{c}\text { Ovulation } \\
\text { incidence } \\
(\%)\end{array}$ \\
\hline 12 & 2 & 0 & 2 & 0 & 4 & $\begin{array}{ll}0 & (0)\end{array}$ \\
\hline 16 & 2 & 0 & 2 & 0 & 4 & $\begin{array}{ll}0 & (0)\end{array}$ \\
\hline 20 & 2 & 0 & 2 & 0 & 4 & $\begin{array}{ll}0 & (0)\end{array}$ \\
\hline 24 & 6 & 3 & 4 & 2 & 10 & $5 \quad(50)$ \\
\hline 28 & 2 & 2 & 2 & 2 & 4 & $4(100)$ \\
\hline 32 & 2 & 2 & 3 & 3 & 5 & $5(100)$ \\
\hline 36 & 2 & 2 & 1 & 1 & 3 & $3(100)$ \\
\hline
\end{tabular}

\section{Plasma progesterone and $\mathrm{LH}$ profiles around oestrus}

Mean plasma progesterone and LH profiles, normalized about the start of synchronization treatment (i.e. cloprostenol injection/CIDR device withdrawal) and the onset of oestrus (Hour 0), are presented in Fig. 2. Mean plasma progesterone concentrations of Group 1 does $(\mathrm{N}=4)$ exhibited a gradual decline from $\sim 8 \mathrm{ng} / \mathrm{ml}$ at the time of cloprostenol injection to $<1.0 \mathrm{ng} / \mathrm{ml} 26 \mathrm{~h}$ later. Does in Group $2(\mathrm{~N}=4)$ showed a more rapid decline to values $<1.0 \mathrm{ng} / \mathrm{ml}$ by $2 \mathrm{~h}$ after CIDR device withdrawal. Animals in both groups exhibited similar mean plasma LH profiles, with the onset of the preovulatory LH surge occurring at the onset of oestrus. Maximal mean LH surge values of $\sim 30 \mathrm{ng} / \mathrm{ml}$ were attained $6 \mathrm{~h}$ after the onset of oestrus.

Endocrine data for 2 does sampled at 2 -h intervals about oestrus were excluded from the profiles in Fig. 2. A doe from Group 1 did not exhibit oestrus until $72 \mathrm{~h}$ after the cloprostenol injection, just before withdrawal of the last blood sample. This doe failed to exhibit a preovulatory LH surge during the sampling period, although it ovulated between 16 and $24 \mathrm{~h}$ after the onset of oestrus. Its preovulatory endocrine profile was characterized by erratic fluctuations in plasma progesterone concentrations (up to $4 \mathrm{ng} / \mathrm{ml}$ ) throughout the sampling period. The other doe (W45) was one of two Group 2 does that failed to exhibit oestrus after CIDR device withdrawal because it had a functional corpus luteum (Fig. 3). Thrice-weekly blood samples from these 2 does show that CIDR device withdrawal was not associated with a rapid decline in plasma progesterone concentrations until 10-12 days later, when oestrus was finally exhibited. Samples taken every $2 \mathrm{~h}$ for $72 \mathrm{~h}$ from CIDR device withdrawal with Doe W45 showed a steady secretion of luteal progesterone (6-10 ng/ml) throughout the 72-h period, with no changes in LH secretion (Fig. 3).

\section{Discussion}

Previous research on fallow deer has shown that the onset of behavioural oestrus invariably coincides with the onset of the preovulatory LH surge, and that the amplitude and duration of the 


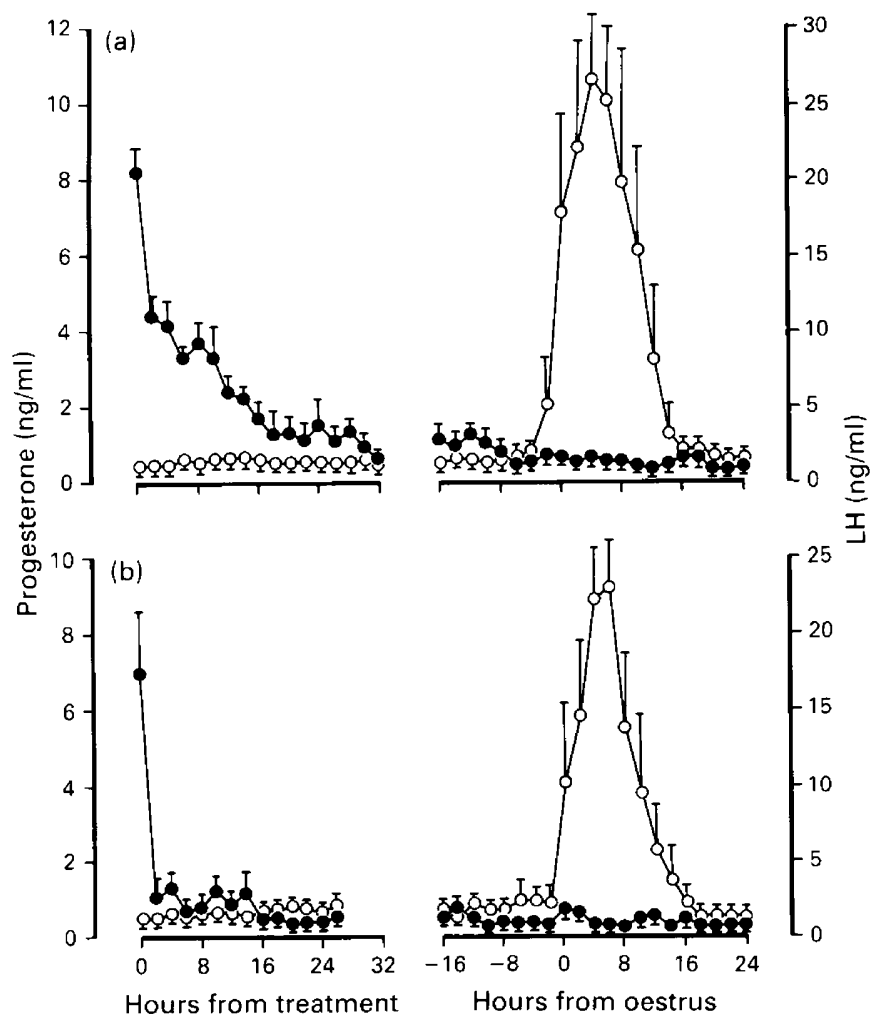

Fig. 2. Profiles of mean ( \pm s.e.m.) plasma progesterone $(\Theta)$ and $\mathrm{LH}(O)$ concentrations of fallow does from samples collected at 2 -h intervals for a 72 -h period spanning synchronized oestrus. The data are normalized from the start of the synchronization treatment and/or the onset of oestrus. (a) Group 1 does, prostaglandin-induced oestrus ( $\mathrm{N}=4$ does); (b) Group 2 does, progesterone-induced oestrus $(\mathrm{N}=4$ does $)$.

LH surge are relatively uniform among individual does (Asher et al., 1986; Asher \& Thompson, 1989). This has been confirmed in the present study. Therefore, the onset of oestrus, which can be detected by frequent surveillance of buck mating marks (Asher, 1985), is a reliable predictor of the temporal occurrence of the preovulatory LH surge and an ideal reference point from which to time laparoscopic examination of ovaries to assess the occurrence of ovulation. The data obtained in the present study indicate that for prostaglandin- and progesterone-synchronized cycles, ovulation occurs around $24 \mathrm{~h}$ after the onset of oestrus and $18 \mathrm{~h}$ after the LH peak. The latter is relatively earlier than in sheep (22-26 h; Cumming et al., 1973), cattle (23-29 h; Henricks et al., 1970; Schams et al., 1977), swamp buffaloes (26-29 h; Kanai \& Shimizu, 1986) and goats (16-24 h; Mori \& Kano, 1984).

Our results on plasma progesterone clearance and on the onset of oestrus after cloprostenol injection have been consistent with published results (Asher \& Thompson, 1989) and indicate considerable potential for use in artificial insemination programmes. However, in 3 separate trials involving the use of intravaginal CIDR devices, the mean ( \pm s.e.m.) intervals from withdrawal to oestrus onset have been variable $(34.1 \pm 2.5 \mathrm{~h}$, present study; $53.3 \pm 3.6 \mathrm{~h}$, Asher et al., 1986; $43.5 \pm 5.9 \mathrm{~h}$, Asher \& Thompson, 1989). Factors that may have contributed to this variation include timing of CIDR device withdrawal relative to the natural rut, CIDR device insertion duration (9-14 days), and type of CIDR device (type-S or type-G). Irrespective of the form of synchronization of oestrus treatment, the present study showed that there was less variation in the interval from the onset of oestrus (or peak LH concentration) to ovulation than in the interval from 

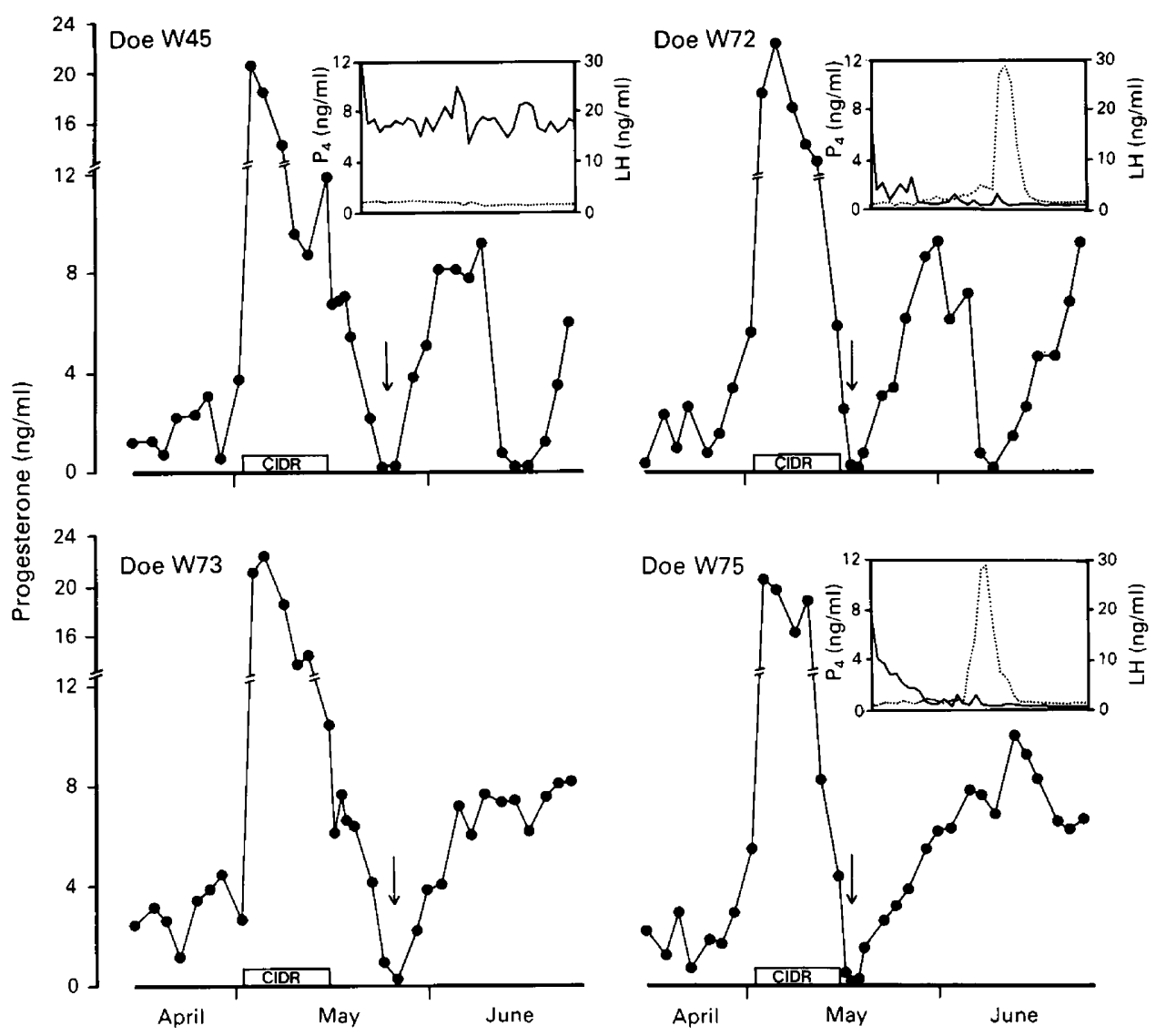

Fig. 3. Profiles of plasma progesterone (O) from thrice-weekly collections, and inset profiles of plasma progesterone $(-, \mathrm{P} 4)$ and $\mathrm{LH}(\cdots)$ from samples collected at 2 -h intervals for a $72-\mathrm{h}$ period from CIDR device withdrawal (except for Doe W73), for fallow does failing to exhibit oestrus after CIDR device withdrawal due to the presence of an active corpus luteum (Does W45 and W73) or representative of those exhibiting oestrus after CIDR device withdrawal (Does W72 and W75).

the end of the synchronization treatment (prostaglandin administration/progesterone withdrawal) to oestrus or ovulation. As artificial inseminations are normally performed at fixed intervals from synchronization treatment rather than detection of induced oestrus, further studies to improve conception rates may need to investigate factors affecting synchrony of oestrus and time to onset of oestrus.

The plasma progesterone concentrations during 13 days of CIDR device (type-G) treatment were higher than occurring naturally during normal luteal cycles, and therefore should have been adequate in inhibiting ovulation. However, 2 does failed to exhibit oestrus immediately after device withdrawal and each possessed an active corpus luteum for a further 10-12 days. This apparent failure of type-G CIDR devices has not been recorded for type-S CIDR devices (Asher et al., 1986; Asher \& Thompson, 1989). Plasma progesterone profiles of these does (Fig. 3) provide no clues as to the possible cause of failure of ovulation suppression. Alternatively, these 2 does may have exhibited extremely long luteal cycles, with ovulation occurring before CIDR device insertion. If this is the case, the inclusion of prostaglandin treatment towards the end of CIDR device insertion would ensure successful synchronization at device withdrawal. 
The incidence of multiple ovulations in fallow deer is very low (Armstrong et al., 1969; Chapman \& Chapman, 1969, 1975). One doe in the present study exhibited a double ovulation following cloprostenol administration. High plasma progesterone concentrations $(>13 \mathrm{ng} / \mathrm{ml}$ ) 12-14 days after ovulation indicate that both ovulating follicles luteinized during the oestrous cycle (Asher \& Smith, 1987). This represents a rare event within the studied population as evidence of natural multiple ovulations is scarce, involving a single observation of natural twins born in 1984 .

Does in the present study were mated by fertile bucks at the induced oestrus but only 5 of the 17 mated does conceived. This contrasts with high conception rates $(>80 \%)$ recorded in another study in which the endocrine status of does was also closely monitored during induced oestrus (Asher \& Thompson, 1989). It is possible that physical manipulation of the ovaries around ovulation disrupted the passage of the ovum through the reproductive tract. This has implications for conduct of laparoscopic intrauterine insemination, in which disturbance of the reproductive tract must be minimized to avoid ovum wastage.

We thank J. Parr, J. Konlechner, D. Ward and H. Humble for assistance during blood sampling and laparoscopy; and G. Lints for performing hormone assays.

\section{References}

Armstrong, N., Chaplin, R.E., Chapman, D.I. \& Smith, B. (1969) Observations on the reproduction of female wild and park fallow deer (Dama dama) in south England. J. Zool., Lond. 158, 27-37.

Asher, G.W. (1985) Oestrous cycle and breeding season of farmed fallow deer, Dama dama. J. Reprod. Fert. 75, 521-529.

Asher G.W. \& Smith, J.F. (1987) Induction of oestrus and ovulation in farmed fallow deer (Dama dama) by using progesterone and PMSG treatment. $J$. Reprod. Fert., 81, 113-118.

Asher G.W. \& Thompson, J.G.E. (1989) Plasma progesterone and $\mathrm{LH}$ concentrations during oestrous synchronization in female fallow deer (Dama dama). Anim. Reprod. Sci. 19, 143-153.

Asher, G.W., Barrell, G.K. \& Peterson, A.J. (1986) Hormonal changes around oestrus of farmed fallow deer, Dama dama. J. Reprod. Fert. 78, 487-496.

Asher, G.W., Adam, J.L., James, R.W. \& Barnes, D. (1988) Artificial insemination of farmed fallow deer (Dama dama): fixed-time insemination at a synchronized oestrus. Anim. Prod. 47, 487-492.

Asher, G.W., Jabbour, H.N., Morrow, C.J. \& Langridge, M. (1990) Reproductive physiology and controlled breeding of farmed fallow deer (Dama dama). Proc. Deer Course for Veterinarians, No. 7. Deer Branch New Zealand Veterinary Association, Auckland.

Chapman, D.I. \& Chapman, N. (1969) Observations on the biology of fallow deer (Dama dama) in Epping Forest, Essex, England. Biological Conservation 2, $55-62$.

Chapman, D.I. \& Chapman, N. (1975) Fallow deer: their History, Distribution and Biology. Terence Dalton Ltd, Lavenham, UK.

Cumming, I.A., Buckmaster, J.M., Blockey, M.A. deB., Goding, J.R., Winfield, C.G. \& Baxter, R.W. (1973)
Constancy of interval between luteinizing hormone release and ovulation in the ewe. Biol. Reprod. 9, 24-29.

Kanai, Y. \& Shimizu, H. (1986) Changes in plasma concentrations of luteinizing hormone, progesterone and oestradiol-17b during the periovulatory period in cyclic swamp buffaloes (Bubalus bubalis). Anim. Reprod. Sci. 11, 17-24.

Henricks, D.M., Dickey, J.F. \& Niswender, G.D. (1970) Serum luteinizing hormone and plasma progesterone levels during the estrous cycle and early pregnancy in cows. Biol. Reprod. 2, 346-351.

Maxwell, W.M.C. (1984) Current problems and future potential of artificial insemination programmes. In Reproduction in Sheep, pp. 291-298. Eds D. R. Lindsay \& D. T. Pearce. Australian Academy of Science, Canberra.

Mori, Y. \& Kano, Y. (1984) Changes in plasma concentrations of LH, progesterone and oestradiol in relation to the occurrence of luteolysis, oestrus and time of ovulation in the Shiba goat (Capra hircus). $J$. Reprod. Fert. 72, 223-230.

Mulley, R.C., Moore, N.W. \& English, A.W. (1988) Successful uterine insemination of fallow deer with fresh and frozen semen. Theriogenology 29, 1149-1153.

Scaramuzzi, R.J., Caldwell, B.V. \& Moor, R.M. (1970) Radioimmunoassay of $\mathrm{LH}$ and estrogen during the estrous cycle of the ewe. Biol. Reprod. 3, 110-119.

Schams, D., Schallenberger, E., Hoffmann, B. \& Karg, H. (1977) The oestrous cycle of the cow: hormonal parameters and time relationships concerning oestrus, ovulation, and electrical resistance of the vaginal mucus. Acta endocr., Copenh. 86, 180-192.

Received 15 January 1990 